\title{
The human-animal relationship: a new field of socio-educational action
}

\author{
Joan-Maria Senent-Sánchez \\ Department of Comparative Education and History of Education, University of Valencia, Spain \\ \{senent@uv.es\} \\ Received on 19 May 2014; revised on 19 May 2014; accepted on 27 May 2014; published on 15 July 2014 \\ DOI: 10.7821/naer.3.2.100-106
}

\begin{abstract}
This article analyses the educational approaches towards the animal-human relationship which have been developed during the last 20 years. The article establishes a chain of states in that relationship and presents the reasons why those states are consecutive or, occasionally, simultaneous.

Next, the different European profiles of social educators are reviewed to see which of these are more open towards educational action with animals, something which could be considered a new field for educators if they have adequate professional training. A series of European (and some American) websites are analysed in order to determine their approach towards the humananimal relationship. Although most of them are related to animalassisted therapy, some francophone and Italian websites show approaches that go beyond that. That could imply an extension of the social educators' field of action. Indeed, French and SouthernEuropean models are closer to that point than the rest of the profiles analysed, in terms of the openness and flexibility they show towards new fields.
\end{abstract}

KEYWORDS: ANIMAL BEHAVIOUR, SOCIAL ACTION, EDUCATORS' TRAINING, EDUCATIONAL THERAPY

\section{INTRODUCTION}

The relationship between animals and humans is a constant in history and has developed into different facets related to subjugation, defence, fear, protection, admiration, company, exploitation, food, transport, fun, etc. Over the last few decades, this relationship has evolved into new facets which have raised new ethical, sanitary and therapeutic issues.

Some of those issues have caused various associations and animal welfare groups to form protest movements in several areas: trade, transport, entertainment, customs and traditions, etc. All of them share a common aim: the protection of animals.

My relationship with animals has been a constant in my life, from a personal point of view more than an intellectual one. When I was a child, we had animals at home, like many other Spanish families from the countryside. Even now, taking care of cats, dogs, chickens, rabbits and ducks is still part of my

\footnotetext{
*To whom correspondence should be addressed:

Facultad de Filosofía y Ciencias de la Educación Universidad de Valencia

Avda. Blasco Ibáñez, 30, 46010

Valencia, Spain
}

domestic daily routine. Furthermore, I have been a bird enthusiast since I was a child. I have carried out observational tasks, I have taken care of nesting boxes in the forest and I have specialised in the breeding of Psittacidae (lovebirds, cockatiels, rosellas...), which I have in big aviaries at home.

Some months ago, I was asked to participate in a conference organised by SPERA-COEESCV (Sección Profesional de Educación en el Respeto a los Animales. Colegio Oficial de Educadoras y Educadores Sociales de la Comunidad Valenciana (España)). It was held at the Faculty of Philosophy and Educational Science and I gave a speech entitled "Education based on respect towards animals: a new field in Social Education". That speech was, indeed, influenced by my own experience: if the human-animal relationship is to become a new field in Social Education, it cannot only be considered based in this respect, since the relationship goes way beyond that.

The aim of this article is to analyse new approaches to education which have recently appeared in Spain and the rest of Europe, which consider the relationship between animals and humans, and to determine to what extent these approaches constitute, or should constitute, a new field in socio-educational circles and, therefore, a new field in Social Education. All of this needs to be contextualised from the point of view that Social Education is a discipline which is under construction. Educators' identities, scopes and profiles are constantly changing and being redefined, as Caride states: "the progressive recognition of social educators and pedagogues as professionals of education means that more and more effort is needed to define their symbols of identity in order to promote the educational role of society, to increase the socialising possibilities of education and to diversify its professional scope into a wide network of fields and socioeducational programmes" (2010, p. 93). Another change which should be borne in mind is the evolving context of initial qualifications concerning pedagogy after the European Convergence Process of Bologna (Senent, 2005), which meant that Social Education stopped being a three-year diploma and became a four-year degree.

This situation implies two things: the animal-human relationship needs to have educational features and it needs to be included within the abilities of each country's social educator profile, which is closely related to the model of educator present in each country.

Based on that, this article aims to analyse those two issues: the different approaches within the animal-human relationship based on a socio-educational viewpoint and whether they fit into the different models of social educators in Europe. The final aim is to determine whether that relationship can become a new field in 
Social Education and in which model or models it fits best based on the nature of the educators' intervention.

\section{MATERIALS AND METHOD}

A double methodology has been used to analyse the approaches explained in the previous section. On one side, a series of European websites of associations, groups and schools dealing with the relationship between educators and animals have been analysed:

- Animal Assisted Intervention International

(www.animalassistedintervention.org)

- Wamiz, le site des animaux de compagnie

(http://wamiz.com/)

- Le Blog de la mediation animale

(http://www.mediation-animale.org/)

- Mujer. Entrepadres

(http://entrepadres.imujer.com/2008-06-20/728/relacion-entreninos-y-animales)

- Deabyday

(http://www.deabyday.tv/genitori-e-bambini/educazione/guide /2225/Come-educare-i-bambini-al-rapporto-con-glianimali.html)

- Enfant-différent (http://www.enfant-different.org)

- Association suisse de zoothérapie

(http://www.zootherapiesuisse.ch)

- Portal de Terapia y Educación asistida por animales de compañía (http://www.fundacion-affinity.org/)

- Animal-Services

(http://www.animal-services.com/metier.php3)

- Webconsultas (http://www.webconsultas.com)

- Tempostretto (http://www.tempostretto.it/news/attivit-extracurriculare-via-progetto-didattico-educazione-salute-rapportorelazionale-uomo-animale.html)

- Animali nel mondo

(http://www.animalinelmondo.com/notizie/cani/622/ilrapporto-tra-cane-e-bambino.html)

- Therapet Fondations (http://www.therapet.org/)

- Animal-Assisted Activites Overview - Pet Partners

(http://www.petpartners.org/page.aspx?pid=319)

- Guidelines for Animal Assisted Activity

(https://www.avma.org)

- Creixem junts (http://www.creixemjunts.cat)

- Canis felis. Hospital veterinari (http://www.canisifelis.com)

- Asociación de zooterapia de Extremadura

(http://www.zooterapiaextremadura.org/)

- Associació Catalana de Zooterapia

(http://www.zooterapias.com/)

- Society for Companion Animal Studies

(http://www.scas.org.uk/)

- Fondation Adrienne et Pierre Sommer

(http://www.fondation-apsommer.org/fr/index.php)
- AFIRAC. Association Française d'Information et de Recherche sur l'Animal de Compagnie (http://www.afirac.org)

- Delta society: Helping dog, helping people

(http://www.deltasociety.com.au/)

- AOTA. American Occupational Therapy Association

(http://www.aota.org/Publications-

News/AmericanJournalOfOccupationalTherapy.aspx)

- Kalshan goldies (http://www.kalshan-goldies.com/)

And on the other side, the analysis of the different European social educators' profiles has been carried out through previous comparative analysis conducted by myself (Senent, 1994; Ruiz y Senent, 2003) and by others who deal with the evolution of profiles and professional abilities (AIEJI, 2009) and with the relationship between profiles and different training approaches, especially within the francophone model (ONISEP, 2013), as it is the oldest and most specialised.

\section{RESULTS AND DISCUSSION: THE ANIMAL- HUMAN RELATIONSHIP WITHIN THE EUROPEAN SOCIO-EDUCATIONAL ACTION}

In European and American scientific literature, the educational relationship concerning animals has been predominantly studied through zootherapy or animal-assisted therapy (AAT), which has experienced an increasing development over the last 20 years and has seen the promotion of the therapeutic side of this relationship.

Although this state is currently the most important one in the educator-animal relationship, I believe we cannot leave behind previous states in that relationship, which allow us to understand AAT and the previous, progressive evolution of the humananimal relationship attached to it. That has led me to try to define a state wheel within that relationship.

\subsection{States within the educator-animal relationship}

The state wheel I am presenting in this section emerges from my own observations of the human-animal relationship and from the analysis of publications and webs which deal with it. I understand this set of states as being progressive, from an educator-animal perspective of the relationship rather than simply from a human-animal one, and also considering that relationship a new possible field of socio-educational action. In a deeper analysis, we could accept that some of those states could occur simultaneously, but that would undermine the validity of the content.

The following section shows how the different European social educators' profiles tend towards or away from that relationship depending on whether those professionals' actions are open or indisposed towards new fields of action which were not expected just ten years ago. However, due to the fact that the social educators' job is constantly changing and being adapted to social needs, those new fields of action do occur in the different social contexts of the European countries, as well as in the new profiles attached to them. Currently, socio-educational actions go beyond mere educational accompaniment —which differs greatly from the francophone model - or educational support which is the main conception of the English-speaking and the Germanic models. 


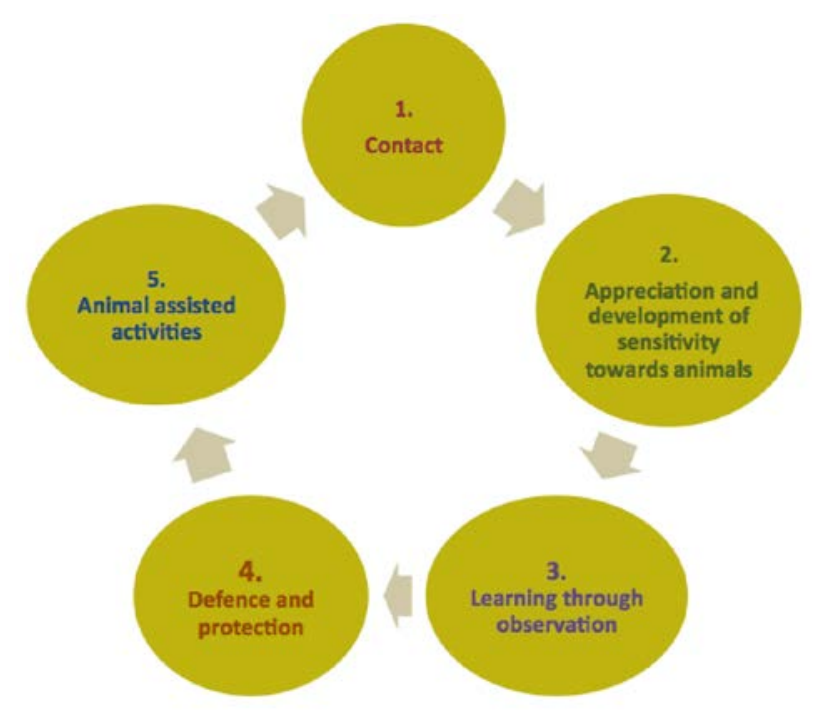

Figure 1. States of the human-animal relationship

\subsubsection{Contact with animals}

The starting point of any educator-animal relationship goes back to a previous stage in which the person develops a common history and a special sensitivity towards animals as a precedent of their educational relationship. I am not suggesting that an educator who works with animals must have previously been a farmer. However, that special sensitivity towards animals cannot be developed if there has not been a common history, even if it has only been that of having one or several pets and having developed a special relationship with them. In any case, this first stage allows the development of the second one, since sensitivity towards animals is not acquired from a strictly intellectual or conceptual approach.

Contact does not imply ownership, but closeness. What I am trying to say is that this first stage represents common experiences and, consequently, memories of them which will allow the observation of the animal's behaviour.

\subsubsection{Appreciation and development of sensitivity towards animals}

It is difficult to think of a relationship between an educator and an animal if the former has not developed sensitivity towards the latter. How could an educator work with a dog or a horse they fear? Experiences with animals must allow one to overcome the state of precaution towards them and for that to evolve into appreciation, esteem and, in most cases, admiration, even though some of those experiences may have been negative.

On the other hand, that sensitivity is perfectly perceived by animals. Dogs detect if we fear them and birds realise if you approach them warily or confidently. It would be impossible to carry out any cooperative action with animals if they perceive feelings of fear or arrogance.

Some people seem to have that special sensitivity as an inherent part of their personality, and this is perceived by animals, while many others acquire it through their own contact and experience with them, in some cases after having overcome fear or precaution towards animals.

In any case, the development of that sensitivity always implies closeness towards animals, which again necessarily implies contact. I have been asked several times if that sensitivity could be developed through virtual proximity (documentaries, films, videos, etc.). I think it could not. Direct physical contact is needed. Animals' perception that we have developed that sensitivity requires our physical presence and interaction with them.

All educational actions are usually assessed based on their result as a product of its process, although the process itself is also assessed as a combination of interpersonal relationships, methodology and communicative acts. Similarly, we can apply this approach to the educator-animal relationship: the development of sensitivity towards animals is a result of the process, since it is through contact that the person will observe and, in some cases, admire the abilities of animals.

Several theories related to biophilia have pointed out that the human brain is structured to pay selective attention to other living creatures and that, based on the contact with other plant or animal species, important influences can occur in knowledge, health and welfare (Wilson \& Kellert, 1993). This explains why, beyond educational approaches, contact with animals could be beneficial for human relations and for the development of sensitivity.

Nevertheless, not everyone thinks the same and there are some people which are opposed to AAT or to automatically establishing a positive effect from the human-animal relationship, they argue that there has been no systematic verification of that axiom (Danten, 2012). Other people do not reject the possessiveness of that relationship, but are rather ambiguous, claiming that there is no clear demonstration to prove as much (Lev, 2003).

\subsubsection{Learning through observation}

The process of learning requires the acquisition of a new behaviour or the modification and existing one. Learning through animals requires us to imitate their behaviour or apply their aptitudes to human life. The observation of animal behaviour frequently makes us understand that certain attitudes produce excellent results, which we then try to imitate. For example, when we observe the cooperation among dogs to control cattle, the cooperative and supportive attitudes among flying geese, the loyalty of horses or dogs, or the hunting strategies used by many animals, etc. we perceive this as behaviour which is susceptible to being imitated or adapted by humans.

While the field of AAT has been widely studied during the last 20 years, little research has been carried out on either the systematisation of learning (Lazzaro, 2011) that imitating animals could provide or the study of observation strategies that learning should undertake to improve its efficiency. As Garcia Rey states: "The relationship of humans with nature and animals has been distorted over the years. Our natural instincts have faded away and some situations we should easily overcome end up being serious problems related to ourselves and our environment. A close contact with a well-trained animal can help us get over common problems such as lack of self-esteem, stress, extreme shyness or lack of confidence. To recognise oneself in a horse, a cat or a dog can happily and nimbly lead us to a healing encounter with our own centre and our place in the universe" (Garcia Rey, 2009, p. 4).

Learning is not only individual. Observational behaviours of young and adult people generate new behaviours in children, as Signes states: "in social learning, children learn from other 
members of our species. Observing family members interact with an animal, embracing it, playing, taking care of it, kissing it, etc. makes children learn that the animal is an affectionate, valuable beloved being” (Signes, 2010, p.4). That occurs in a family context, but it can also be the result of an institutional activity in which learning is not only at an individual level, but at a collective one (Iglesias \& Astorga, 2014), with similar methods to those of gaming, regarding methodology, human relations and the processes of collective communication (Herrero et al. 2014).

\subsubsection{Defence and protection of animals}

This state is in the fourth place because I believe that, from an educator's point of view, it is a stage that comes after the educator is well aware and has got to know and experience the situation of many animals needing defence and protection. When that awareness is acquired only from theoretical approaches it is usually short-lived and not very effective.

Militancy among social action professionals in animal rights movements focussing on the defence and protection of animals has increased considerably, especially in Southern European countries, where traditions involving animal cruelty are still quite important. However, this does not necessarily need to be related to a deeper relationship with animals from a socioeducational sphere. It is often a socio-political commitment that can be developed by anyone from non-educational approaches.

In my analysis, this fourth state is achieved after the three preceding ones: militancy in the defence and protection of animals is achieved after having been in contact with them, appreciating them and having learned from observing them. After all that, the human-animal relationship can start playing a therapeutic role that can lead to the last state.

\subsubsection{Animal-assisted activities}

This is the best-known state when the human-animal relationship is quoted from an educational or therapeutic point of view. In Europe, especially in francophone and Southern European countries, the term used is zootherapy. However, the French tendency (the most important one) is to use that word with a general or global meaning. That is the position of Legrand (2012) when she tries to arrange the different words used in such a new discipline as this, or Adrien and Maurer (2012) in their publication for ANAE. At present, there is a diversity of terms designing very similar activities in which animals are used to help humans: activities, actions, or therapies carried out through animal cooperation, animal mediation or zootherapy.

However, this discipline is not so new, especially in the francophone countries. Some associations such as the Adrienne et Pierre Sommer Foundation have been implementing projects from the 70s and now have more than 300 projects in France, Belgium and Switzerland, as is mentioned on the webpage.

Samuel's proposal (according to Legrand, 2012) is to use the term "animal-assisted actions" to include the two basic concepts of this field: animal-assisted activities and animal-assisted therapies. The first one is defined by the AFIRAC (Association Française d'Information et de Recherche sur l'Animal de Compagnie) as those activities which relate an animal to a professional project or to a specific ability. Animal mediation is a professional activity which requires participants to have specific abilities which cannot be confused with ordinary pleasant activities with animals. The objective of animal-assisted activities (AAA) is to research the positive interactions emerging from an intended human-animal relationship.

Animal-assisted therapies are individual or group actions in which an animal is involved in a therapeutic process based on the specific criteria set by a qualified professional with the objective of improving the cognitive, physical, emotional or social side of a person. The term "zootherapy" is also used to refer to these actions. Elsa Szwarcma (2012) defines it as a therapeutic device based on the interaction between animals and humans. That interaction helps in the process of rehabilitation and improves the person's quality of life.

Occasionally, zootherapy specialises in a very specific therapeutic aspect such as occupational therapy with dogs, which is widely developed in the US and Argentina, where the Asociación Argentina de Terapias Asistidas con Perros defines it as a therapeutic approach in which a dog is used as a co-therapist or link between the patient and the therapist. (AATAP, 2012).

In my analysis of the human-animal relationship as a new field of Social Education I have consciously avoided the identification of the educator-animal relationship with this last notion. It is the most important and most developed one, both in Europe and in the US, and it is very multidisciplinary, restricting the educators' field of action, since its main viewpoints are based on therapy, rehabilitation, psychology or medicine are not in education.

Finally, I believe that it is in these four areas that our research will achieve most. Firstly because they still remain to be researched from an educational point of view, and secondly because they offer a huge range of possibilities for action to educators from very different approaches.

\subsection{The profile of social educators in Europe and their adequacy to the human-animal relationship}

In Europe, socio-educational action has been developed in a very unequal way, from the beginning of that activity to the different types of actions carried out by professionals, called "social educators" in Spain. This has been pointed out in different studies carried out in the last 15 years in order to analyse the evolution (Caride, 2003; Tiana \& Sanz, 2002). That is why we need to analyse the different profiles of social educators. By doing so, we will be able to determine to what extent their relationship with animals -considered from the socioeducational point of view- fits in those profiles.

The different social educators' profiles have emerged through their professional development. That is why the francophone model (France, French-speaking Belgium, Luxemburg and French-speaking Switzerland) is the oldest one. Social educators initially appeared in France at the beginning of the 20th century and especially after the First World War, which caused a huge amount of physical impairments. That situation forced new approaches to treating affected people that went beyond care intervention provided by states or other institutions. At that time, educators began to specialise in a different sort of target audience (physical/psychic impairment and, more recently, social marginalisation). Marginalisation as a field of action for social education emerges in the francophone sphere as a response to the immigration which took place in the area during the late 50s and especially in the 60s and mid-70s (Senent, 2003).

The specialised educator profile is the oldest one. Apart from this, we need to take into account socio-cultural animation and 
its community worker profile. The latter inherited the popular education tradition resulting from the French Revolution and took shape as a proper professional field in the in the 50s, after the Second World War. These two professional profiles educators and community workers - are the bases of a double model constructed on those two pillars. However, there is still more specialisation, since there are different types of educators and community workers. In France, for example, we can find up to ten different training programmes at a higher level which, based on the Spanish perspective, could be considered social educators.

Based on that double approach, francophone community workers move away from the educational relationship we are dealing with and only specialised educators, who are adequately trained in France and Belgium, would fit our human-animal relationship conception.

There is another Central European model based on the Germanic conception of social educator. In Germany, Social Education is called Social Pedagogy and has been closely linked to universities, which means a high level of abstraction and theory. This social pedagogue profile is linked to that of the educator, which is closer to professional action, they are trained at Educators' Schools which are indirectly linked to the universities. Those two training itineraries are not symmetrical, since the former is accessed from the Gymnasium and the Abitur test, while the latter is accessed from the Realschule or the Hautptshule and some of the later vocational possibilities (Senent, 1994).

The German approach is based on two profiles, but with a big difference from the French one: both of them are based on a more global, polyvalent perspective. What makes them different is the level of involvement in professional action and not the field of action, as happened with the francophone model. The Germanic model applies to German, Dutch, Danish and Austrian educators. In all cases, we find profiles which are closer to pedagogy than to social services. They share training places with teachers and educators and end up achieving a professional action profile which is educational rather than social, which makes them very different from social service workers (SDBB, 2014).

From a profile-based point of view, Germanic educators fit well into the human-animal relationship action as it is considered in this article. However, some types of that relationship, especially AAT, are closer to this profile of educators due to the psychological and pedagogical training they receive in their initial training and the training they continue to receive after their studies.

In Northern Europe, there is a third type of profile, based on its corresponding training programme. This model applies to Anglophone countries (Great Britain and Ireland) and to some Scandinavian countries. The strong tradition of voluntary work existing in Great Britain and the US defines the type of action carried out by social educators. Many functions developed by them in other models and profiles are carried out by voluntary workers here. Professional social action by social workers, social and community workers and care workers under this model is done from a global perspective: social work, specialised education and community work are carried out by the same professionals. However, some more specialised profiles have emerged in the last 15 years, like youth and community workers, social educators, community development workers and community support workers (Eldford, 2014), which are closer to some francophone or Southern European profiles.

The British tradition of human-animal relationship dates back in time and is developed under its own specific conception. In some cases, this relationship is developed from associations of voluntary workers, while the majority of professionals work from a physiological and physiotherapeutic point of view or from the different functional dysfunctions. In any case, the type of actions carried out does not match with the usual actions carried out by social Workers, social educators or social and community workers, who usually have a more global approach when carrying out socio-educational actions.

Finally, there is a fourth training model which applies to different realities but does have some common features. It is the Southern European or Mediterranean model, which applies to Portugal, Spain, Italy and Greece. A first common feature is the fact that training in Social Education has been established very recently, 30 years or less depending on the country. Its adscription to higher education is even more recent in some countries, only ten years ago (Sánchez, 2012).

Another factor is that all those countries' social services are less developed than in the Central and Northern Europe. That makes it difficult to achieve a high level of specialisation, which would indeed be far away from reality. In these countries, the State is the main employer of educators, while the rest of countries have developed a private management model. That means public investment in social services defines the route for the training development of educators. Consequently, professionals have a polyvalent profile that allows them to deal with different situations, and specialisation occurs with time, depending on the field they work in.

Educators are trained at a higher education level, mainly university, and through vocational training of a middle and higher degree. In the latter, new training programmes have been implemented in recent years, though the level of involvement and responsibility of the resulting professionals is much lower than that of professionals coming from higher education levels. The fact that Mediterranean training programmes are quite recent may have made them have curricula with a big theoretical component and with a rather limited practical side compared to the francophone and Germanic models. However, the show a higher level of flexibility, as they are models with a short and very scarcely established history, professionally speaking.

From a profile point of view, Mediterranean Social Education training does not include any content related to the humananimal relationship theory analysed in this article, or at least at an initial level. However, it happens the same with other fields which are not included in that initial training, in which professionals specialise through permanent training.

On the other hand, this model shows a common feature that is different from the other three models: the adaptability to new fields of action. The fact of being the professional model with a shorter history implies that that history or tradition also has little influence on the educators' profile, which allows them to access new fields of action more quickly than in other models. From that perspective, the educational human-animal relationship could easily be established as a new field of action, as has recently happened with other fields such as school social education, mediation, socio-environmental education, etc. In this sense it could be argued that this is the model with a higher degree of openness to accept our object of study as a new field of action, even though "we could find some dissociation 
between academic studies and their requirements, and professional practice, which would be unrelated, watered down and socially and professionally unrecognised as they should" (Viché, 2008). In this sense, although this would be the profile with a higher level of openness towards new fields of action, it could also be the one in which it would me more difficult to carry on educational practice programmes within the professional sphere.

\section{CONCLUSIONS}

The analysis of the websites compiled in the first section shows that there are different approaches for professional animalassisted actions, regardless of their being proper actions or therapies (zootherapy), which are the most widespread activity in the European and American contexts. That diversity has lead the author to analyse the chain of states involved in the humananimal relationship and which lies under those approaches. He then explains the temporary correlation of those states needed for a real animal-based socio-educational action which is based on the educators' own personal experience and contact with animals, allowing them to reflect and use that relationship as an educational tool. That way, educators will be able to go beyond the therapeutic approach and also use a training perspective in their educational relationship with animals (four initial states).

The second part of the article analyses to what extent animalbased actions fit in the different educators' profiles which exist in the European context. The features of those profiles have been analysed in order to define which of them could be established in a new field of action for educators and which of them are flexible enough to acceptably incorporate that new field of action.

The feature analysis of animal-based socio-educational actions and professional profiles shows that the Anglophone and the Mediterranean models seem to be the most adequate at incorporating that new field. However, the more holistic approach of the Scandinavian and British model makes it difficult to implement a more specialised field. On the other hand, Southern European models seem to be more open to new fields of action, since those models are still under construction.

The fact that the Mediterranean social educator profile is more open to new fields of action does not mean that their initial training curricula include specific training in subject of this article. As opposed to what happens with the professional profile, training curricula are quite restricted to scientific conceptual approaches of their discipline and do not cover the real professional needs educators will encounter once they have finished their studies.

It seems quite logical to say that, though the human-animal relationship can be considered a new field of action for social educators, training in this field will not be included in their university curriculum in the near future. Therefore, that extra training will have to be offered by professional entities professional associations, trade unions, etc. - and the various new associations related to the human-animal relationship. Although most of them focus mainly on the therapeutic aspects of that relationship, some of them are starting to offer a wider range of activities more suitable for the role of educators.

A cursory review of the Official Masters degrees which have been offered by Spanish universities during the last five years for Social Education students and professionals shows that they are quite scarce. I conclude that the postgraduate level will neither offer the kind of specialisation concerning the educatoranimal relationship. None of the masters analysed take that field into account. Moreover, it would be very difficult for universities to find lecturers with a high level of specialisation in this area to teach courses of this sort.

Nevertheless, if we believe that the educator-human relationship can become a new field in Social Education, we should start to move forward. One of the first steps could be to accept it as a field of internship for undergraduate students. Another step could be to consider it as a research topic for future degree or Master's final projects. Talks, collaborative projects or conferences could be organised together with the associations related to the different aspects of the human-animal relationship, and so on.

Certainly, we do need to move forward. The latest new fields included in Social Education have required a long period to become well established. Also, it is a fact that professional educators have already started to act in this field, though with little, less than systematic training. Nevertheless, they have been moved by the certainty that an educational human-animal relationship can be a very interesting tool to work with people's habits and attitudes, which is one of the aims of Social Education.

\section{REFERENCIAS}

AIEJI (Association Internationale des Éducateurs Sociaux) (2009). Les compétences professionelles des éducateurs sociaux. Retrieved from http://aieji.net/wp-content/uploads/2010/12/Professionalcompetences-FR.pdf

AATAP (Asociación Argentina de Terapias Asistidas con Perros) (2012). Terapia ocupacional asistida por perros [Website].

Retrieved from http://terapiaconperros.com.ar/\%c2\%bfque-es-laterapia-asistida-con-perros/

Adrien, J., \& Maurer, M. (2012). L'animal dans le soin: entre théories et pratiques. ANAE. Approche Neuropsychologique des Apprentissages chez l'Enfant, 24(117), 119-205.

Caride, J. A. (2002). Construir la educación social como proyecto ético y tarea cívica. Revista de Pedagogía Social, 9, 91-125. doi: 10.7179/PSRI

Caride, J. A (2003). Las identidades de la educación social. Cuadernos de Pedagogía, 321, 67-70.

Caride, J.A (2010). La pedagogía social en España. In V. Nuñez (Ed.), La Educación en tiempos de incertidumbre (pp. 81-112). Madrid: Gedisa.

Danten, Ch. (2012). Remise en question de la zoothérapie. En Le Quebec sceptique, 68, 22-31.

Eldford, J. (2014). Volunteer stories [Web page]. Retrieved from: http://www.vso.org.uk/volunteer/opportunities/community-andsocial-development-hiv-and-aids/community-workers

Estévez, R., Astorga, J., García-González, M., \& Iglesias, J. (2014, Marzo). Intervenciones asistidas por animales en instituciones. Curso de Extensión Universitaria de la UNED.

García Rey, S. (2009). Cabalgando en el viento: La ciencia-arte de la psicoterapia asistida con animales y naturaleza. Madrid: Luciérnaga.

Herrero, D., del Castillo, H., Monjelat, N., García-Varela, A. B., Checa, M., \& Gómez, P. (2014). Evolution and natural selection: learning by playing and reflecting. Journal of New Approaches in Educational Research, 3(1), 26-33. Retrieved from http://www.naerjournal.ua.es doi: 10.7821/naer.3.1.26-33

Lazzaro, A. (2011): Bambini e Cani: verso un approccio corretto. Retrieved from the Istituto Leonardo Murieldo website: http://www.murialdoalbano.it/download/Download/Scuola_Primaria/ I_nostri_lavori/BAMBINI_E_CANI.pdf

Legrand, P. (2012, August 31). Les Interventions assistées par l'Animal [Blog post]. Retrieved from http://www.enfantdifferent.org/selection/75-education/286-mediation-animalezootherapie.html

Lev, E. (2003). Traditional healing with animals (zootherapy): medieval to present-day Levantine practice. Journal of Ethnopharmacology, 85, 107-118. doi: 10.1016/S0378-8741(02)00377-X 
ONISEP (Organisation nationale d'informations professionnelles) (2013). Fiche-Métier Éducateur(trice) spécialisé(e) [Web page]. Retrieved from http://www.onisep.fr/Ressources/UniversMetier/Metiers/educateur-trice-specialise-e

Sanchez, J. F. (2012). La realidad sobre la educación social: La participación como proceso de socialización. Aposta. Revista de Ciencias Sociales, 53, 1-12.

SDDB (2014): Berufe und Ausbildungen [Web page]. Beruf: Sozialpädagoge/-pädagogin HF. Retrieved from http://www.berufsberatung.ch/dyn/1199.aspx?id=6210

Senent, J. M. (1994): Los Educadores Sociales en Europa. Valencia: Publicacions de la Universitat de València.

Senent, J. M. (2003): Desarrollo contemporáneo de la Educación Social. In C. Ruiz (Ed.), Educación Social, viejos usos, nuevos retos. (pp. 59-92). Valencia: Publicacions de la Universitat de València.

Senent, J. M. (2005): Los estudios de Pedagogía en Europa en el contexto de la implantación del proceso de Bolonia y la situación de la Educación Comparada. Revista de Educación Comparada, 11, 95134.

Signes Llopis, M., \& Rodrigo Claverol, M. (2010). Animales de compañía y niños: una relación educativa y terapéutica. Retrieved from http://www.voraus.com

Szwarcma, E. (2012). What is Zootherapy? Retrieved from Kalshan Goldies website: http://www.kalshan-

goldies.com/index.php?option=com_content\&task=view\&id=6\&Itemid= 22\&lang $=$ en

Tiana, A., \& Sanz, F. (2002). Génesis y Situación de la Educación Social en Europa. Madrid: UNED.

Viché, M. (2008). La educación social en España. Vigencia de una práctica: necesidad de una profesión. Quaderns d'animació, 6. Retrieved from http://www.quadernsdanimacio.net 